\title{
Naturalizm w naukach przyrodniczych. Perspektywa chrześcijańska
}

\section{Dwa rodzaje naturalizmu}

Czym zajmują się naukowcy? Odkrywaniem zjawisk zachodzących w przyrodzie. Naukowcy nie tylko opisują zjawiska, lecz próbują umiejscowić je w eksplanacyjnym kontekście fizycznych zasad, praw i pól. Jednakże w naukach przyrodniczych za dopuszczalne uznaje się tylko niektóre rodzaje wyjaśnień, mianowicie odnoszące się wyłącznie do obiektów i zdarzeń przyrodniczych. Tym samym wyklucza się osobiste wybory i działania człowieka lub istot boskich.

Na pierwszy rzut oka to szczególne pojmowanie nauk przyrodniczych mogłoby bardzo przeszkadzać chrześcijańskim uczonym, którym wpajano wiarę $w$ to, że nasze relacje $z$ Bogiem powinny być nierozerwalnie związane z wszelkimi aspektami naszego życia - wliczając $\mathrm{w}$ to badania $\mathrm{w}$ dziedzinie nauk przyrodniczych. Zawsze powinniśmy wysławiać Boga, bez względu na to, czym się zajmujemy. Ale jeśli nie możemy mówić o Bogu $\mathrm{w}$ ramach nauk przyrodniczych, to trudno uznać, że praca naukowa ma charakter chrześcijański. Uczeni chrześcijańscy mogą znaleźć się między młotem a kowadłem — jeśli

* Paul de VRIES, „Naturalism in the Natural Sciences: A Christian Perspective”, Christian Scholar's Review, Summer 1986, vol. 15, no. 4, s. 388-396. Za zgodą Autora z języka angielskiego przełożył Radosław Plato. Recenzent: Józef ZoN, Katedra Biologii Teoretycznej Katolickiego Uniwersytetu Lubelskiego. 
w naukach przyrodniczych dopuścimy odniesienia do Boga, to nie będziemy już uprawiać nauki.

Czy chrześcijanin, który jest naukowcem, musi prowadzić podwójne życie? Czy musi być rozdarty między biblijnym nakazem gloryfikowania Boga we wszystkich rzeczach a wymogiem zawodowym, by nie mówić o Bogu w sprawach naukowych? Sądzę, że nie. Celem moich filozoficznych dociekań jest obrona tezy, że chrześcijanom powinien odpowiadać ten rodzaj naturalizmu, który przyjmowany jest w naukach przyrodniczych.

Celem badań nauk przyrodniczych jest wyjaśnianie przygodnych zjawisk w przyrodzie wyłącznie za pomocą innych przygodnych czynników i kategorii przyrodniczych — praw, pól, prawdopodobieństw. $\mathrm{Z}$ nauk przyrodniczych wyklucza się oczywiście wszelkie wyjaśnienia odnoszące się do istot lub sił nadprzyrodzonych. Wyjąwszy terminy matematyczne i prawdy logiki, przedmioty, o których mówią teorie naukowe, są zawsze przygodne; każdy $\mathrm{z}$ nich jest zależny od innych przedmiotów. Upuszczam ołówek i natychmiast spada on na podłogę. Dlaczego? Stwierdzenie „Bóg tak uczynił” nie byłoby zbyt pouczające $\mathrm{z}$ naukowego punktu widzenia. Podobnie naukowiec nie mógłby stwierdzić, że jakąś konkretną ulewę wywołał indiański taniec deszczu albo modlitwy farmera. Ulewy wyjaśnia się czynnikami przyrodniczymi, takimi jak ciśnienie i temperatura powietrza, a te czynniki uzależnione są z kolei od innych naturalnych czynników.

Krótko mówiąc, w naukach przyrodniczych udziela się wyjaśnień wyrażonych w kategoriach przygodnych, nieosobowych czynników, które stanowią część Wszechświata. Jeśli zanurzę w wodzie dwie naładowane elektrody, zacznie wydzielać się wodór i tlen. Gdybym pisał sprawozdanie $\mathrm{z}$ badań (nawet na chrześcijańskiej uczelni!), nie do przyjęcia byłoby stwierdzenie, że Bóg zaingerował, powodując rozdzielenie się tych pierwiastków. Z perspektywy wyjaśniania naukowego „hipoteza Boga” jest zbędna i niewłaściwa. 
Naturalizm nauk przyrodniczych jest jedynie metodą tej dyscypliny. Rzecz jasna, naukowcy nie mogli odkryć, iż to nie Bóg sprawił, że zjawiska przyrodnicze zachodzą w taki a nie inny sposób. Pierwotne przyczyny lub ostateczne źródła regularności przyrody nie są właściwym przedmiotem zainteresowań żadnej z nauk przyrodniczych aczkolwiek liczni naukowcy nadal żywo i szczerze interesują się tymi zagadnieniami. Przyjęta metoda ogranicza nauki przyrodnicze do poszukiwania wyjaśnień naturalistycznych, co znaczy, że odpowiedzi na pytania należy poszukiwać w samej przyrodzie, w nieosobowym, przygodnym uporządkowaniu i nigdzie indziej. Tak więc nauki przyrodnicze kierują się tym, co nazywam naturalizmem metodologicznym.

Naturalizm metodologiczny jest zupełnie odmienny od naturalizmu metafizycznego. Ten ostatni jest perspektywą filozoficzną, która zaprzecza istnieniu transcendentnego Boga. $\mathrm{Z}$ naturalizmu metodologicznego nic takiego nie wynika, ponieważ ta metodologia naukowa nawet nie podnosi kwestii istnienia Boga. Niestety, te dwa rodzaje naturalizmu często bywają ze sobą mylone. W rezultacie ludziom niezważającym na subtelności filozoficzne wydaje się, że osiągnięcia nauk przyrodniczych, kierujących się naturalizmem metodologicznym, przemawiają na rzecz naturalizmu metafizycznego. To nieporozumienie jest godne ubolewania i z pewnością nie znajduje usprawiedliwienia.

Nauki przyrodnicze zajmują się systematycznym badaniem materii i energii w kontekście naturalizmu metodologicznego. Jeśli więc jakiś naukowiec uważa, że Boga nie ma, a istnieją tylko energia i materia, jak również, że wyłącznie wyjaśnienia naukowe mają jakąkolwiek wartość, to nie może bronić swoich poglądów na podstawie żadnej nauki przyrodniczej, ponieważ wszelkie twierdzenia tego rodzaju dalece przekraczają powszechnie akceptowane kompetencje metodologiczne nauk przyrodniczych. Co więcej, właśnie z tego powodu, że działalność naukowa ograniczona jest do wyjaśnień naturalistycznych, wszyscy powinniśmy uczciwie otworzyć się na inne typy wyjaśniania, kiedy nie pracujemy w laboratoriach lub nie tworzymy teorii naukowych. 
Być może lepiej zrozumiemy to metodologiczne ograniczenie nauk przyrodniczych na konkretnym przykładzie. Gdy po spotkaniu w klubie poprosicie mnie, abym wyjaśnił, dlaczego podniosłem rękę w jakimś głosowaniu, mogę dać wam szczegółowy opis fizyko-chemicznych stanów mózgu, ładunków elektrycznych przepływających przez neurony, skurczów tricepsu i mięśni piersiowych, ruchów kości oraz chrząstek i tak dalej. Innymi słowy, mógłbym udzielić prawdziwego, biologicznego wyjaśnienia tej sytuacji. Jednak taki pokaz naukowej precyzji najprawdopodobniej tylko by was zirytował - nie byłaby to odpowiedź na wasze pytanie. Prosząc mnie o wyjaśnienie, dlaczego zagłosowałem, interesowałyby was aspekty, którymi nauki przyrodnicze, przyjmujące naturalistyczną metodologię, się nie zajmują. Chcielibyście poznać moje cele i powody — kwestie słusznie pomijane na przykład w wyjaśnieniach biologicznych. Mogę wyjaśnić jakieś zdarzenie $\mathrm{w}$ ramach wymogów naturalizmu metodologicznego, a wyjaśnienie to, choćby było prawdziwe i wyczerpujące, wciąż nie stanowiłoby odpowiedzi na postawione pytanie. Wiele zasadnych pytań, dotyczących zjawisk zachodzących w świecie, wykracza poza dziedzinę nauk przyrodniczych.

Co ciekawe, współcześnie istnieją dwie znaczące grupy ludzi, które usiłują zniekształcić obraz nauk przyrodniczych: $z$ jednej strony są to zwolennicy ewolucjonistycznego scjentyzmu (na przykład Carl Sagan), a z drugiej — kreacjonistycznego biblicyzmu (zwłaszcza Henry Morris). Żadna $z$ tych grup, aby osiągnąć własne cele, ewidentnie nie zamierza respektować naturalizmu metodologicznego w naukach przyrodniczych, ich obszaru kompetencji, ograniczonego do systematycznych badań materii i energii. Respektując właściwą rolę nauk przyrodniczych, musimy sprzeciwić się zarówno propozycjom biblicystów, jak i ewolucjonistów. Jedni i drudzy (świadomie bądź nie) wykorzystują dobre imię nauk przyrodniczych do realizacji swoich programów ideologicznych. Sukces naturalizmu metodologicznego nie stanowi jednak żadnego zagrożenia dla prawdy chrześcijańskiej. 


\section{Punkt rozbieżności}

Perspektywę całkowicie różną zarówno od ewolucjonistycznego scjentyzmu, jak i kreacjonistycznego biblicyzmu, która wydaje się niezgodna $\mathrm{z}$ naturalizmem metodologicznym w naukach przyrodniczych, prezentuje pewna praca powszechnie szanowanego filozofa chrześcijańskiego, Nicholasa Wolterstorffa. W książce Reason within the Bounds of Religion [Rozum w ryzach religii] Wolterstorff opisuje i broni roli czegoś, co nazywa ,przekonaniami kontrolnymi” (control beliefs). Jego zdaniem przekonania kontrolne funkcjonują dwojako: przez wzgląd na nie pewne teorie odrzucamy, a inne tworzymy. ${ }^{1}$ Ogólnie rzecz biorąc, formułujemy rozmaite teorie tak, by „,dobrze odpowiadały" naszym konkretnym przekonaniom kontrolnym, nie zaś aby były z nimi niezgodne. ${ }^{2}$ Co więcej, Wolterstorff twierdzi, że „przekonania religijne uczonych chrześcijańskich powinny funkcjonować jak przekonania kontrolne podczas opracowywania i oceniania teorii". ${ }^{3}$

Czy chrześcijańskie przekonania religijne powinny kierować rzeczywistą pracą zawodową naukowców, którzy są chrześcijanami? Wolterstorff sądzi, że powinno tak być, aby nie popaść w konformizm wobec nauki. Nie powinniśmy przecież — ,z perspektywy autentycznej chrześcijańskiej wiary” — zakładać, że nauka jest i zawsze będzie taka sama. Czyniłoby to z nas duchowych „braci” logicznych pozytywistów ${ }^{4}$ - aczkolwiek obecnie logiczni pozytywiści są, na szczęście, na wymarciu! Wolterstorff słusznie wskazuje, że ,żadna teoria nigdy nie jest w pełni autonomiczna”, gdyż każdy uczony „konfrontuje świat z całą siecią teoretycznych i nieteoretycznych przekonań". ${ }^{5}$ Gdy mię-

\footnotetext{
${ }^{1}$ Por. Nicholas Wolterstorff, Reason within the Bounds of Religion, Eerdmans, Grand Rapids 1976, s. 64.

${ }^{2}$ Por. Wolterstorff, Reason..., s. 64.

${ }^{3}$ Wolterstorff, Reason..., s. 66 [wyróżnienie w oryginale].

${ }^{4}$ Por. Wolterstorff, Reason..., s. 26.

${ }^{5}$ Wolterstorff, Reason..., s. 39.
} 
dzy jakąś atrakcyjną teorią a siecią aktualnych przekonań uczonego zachodzi sprzeczność, należy zrezygnować albo z tej teorii, albo z pewnych przekonań. ${ }^{6}$

Ukazawszy, w jaki sposób powinny funkcjonować przekonania kontrolne, Wolterstorff ubolewa nad tym, że uczeni chrześcijańscy nie uwzględniają swoich religijnych przekonań w pracy naukowej. ${ }^{7}$ Smuci go, że ogólnie pojmowana wiara w Boga jako Stwórcę ,,nie ma żadnego wpływu na programy badawcze $w$ obrębie biologii". ${ }^{8}$ Zdaniem Wolterstorffa przyczyn takiego stanu rzeczy należy upatrywać w tym, że uczeni chrześcijańscy nie rozumieją roli, jaką odgrywają przekonania kontrolne, nie rozwijają chrześcijańskich wzorców myślenia, nie znają teologii oraz filozofii chrześcijańskiej i mają słabą wyobraźnię. ${ }^{9}$

Nie ulega wątpliwości, że to smutne zjawisko jest aż nazbyt powszechne wśród chrześcijańskim uczonych — zarówno w obrębie nauk przyrodniczych, jak i poza nimi. Ocena Wolterstorffa jest trafna, jednak jego ujęcie natrafia na kilka trudności. Ma ono trzy poważne mankamenty, które sprawiają, że ścisłe przestrzeganie jego atrakcyjnej wizji nie jest ani pożądane, ani możliwe. Zanim sam odwołam się do pewnych chrześcijańskich ,przekonań kontrolnych” w celu obrony naturalizmu metodologicznego w naukach przyrodniczych, pokrótce wyjaśnię najpierw, w czym kryje się słabość poglądu Wolterstorffa.

Po pierwsze, wprawdzie określony przez Wolterstorffa wymóg unikania sprzeczności oraz nadawania spójności wszystkim naszym rozmaitym przekonaniom z pewnością należy uznać za cnotę, ale jest on także niezmiernie niejednoznaczny. Ze względu na różnorodność naszych „gier językowych” twierdzenie jednej teorii w ramach danej dyscypliny tylko pozornie może przeczyć twierdzeniu innej teorii w ramach innej dyscypliny. Owa „sprzeczność” jest często pozorna.

\footnotetext{
${ }^{6}$ Por. Wolterstorff, Reason..., s. 39.

${ }^{7}$ Por. Wolterstorff, Reason..., s. 101.

${ }^{8}$ Wolterstorff, Reason..., s. 101 [wyróżnienie dodane].

${ }^{9}$ Wolterstorff, Reason..., s. 101-104.
} 
Podobnie twierdzenie jakiejś teorii naukowej może jedynie z pozoru przeczyć jakiejś historycznej doktrynie chrześcijańskiej. Łatwo dać się zwieść powierzchownej gramatyce i mylnie porównywać ,,jabłka z pomarańczami" - albo nawet z kolorem pomarańczowym! Na przykład w fizyce możemy przyjąć, że całkowita ilość materii i energii jest stała. W ramach fizyki twierdzenie to jest prawdziwe i rzetelnie udokumentowane. Niemniej chrześcijanie (czy to będący fizykami, czy nie) powszechnie wierzą, że to Bóg powołał materię i energię do istnienia. Wydaje się więc, że ilość materii i energii nie zawsze była stała. To religijne przekonanie nie przeczy jednak wspomnianemu wyżej twierdzeniu fizyki, ponieważ nigdy nie wchodzą one ze sobą w kontakt umieszczone są w zupełnie innych kontekstach. Ustalone granice dyscyplin zwykle uniemożliwiają przyznanie przekonaniom religijnym większego autorytetu niż twierdzeniom teoretycznym.

Należy także zauważyć, że w późniejszych publikacjach Wolterstorff znacznie osłabił swój wymóg spójności. Na przykład w artykule „Can Belief in God Be Rational If It Has No Foundations?" [Czy wiara w Boga może być racjonalna, jeśli nie ma podstaw?] częstokroć bagatelizuje on znaczenie logicznej spójności, rozumowania oraz racjonalności (jest to wyraz jego obecnego, Reidowskiego podejścia). ${ }^{10}$ Wolterstorff jest teraz bardziej świadomy pewnych potencjalnych pułapek, związanych z próbami wprowadzenia koherencji.

Po drugie, Wolterstorff słabo uzasadnia tezę, że przekonania kontrolne powinny mieć wpływ na formułowanie i akceptację teorii. Oczywiście jego ujęcie może być słuszne, nawet jeśli nie daje dobrych wskazówek, jak należy je realizować. Jednak brak choćby jednej takiej wskazówki nasuwa poważne wątpliwości co do właściwego zrozumienia lub sposobu realizacji jego zaleceń.

$\mathrm{Z}$ jednej strony przedstawia on tylko dwa przypadki, w których, jak twierdzi, chrześcijańskie przekonania kontrolne powinny wpływać

\footnotetext{
${ }^{10}$ Artykuł ten został opublikowany w: Alvin Plantinga and Nicholas Wolterstorff (eds.) Faith and Rationality, University of Notre Dame Press, Notre Dame, Indianapolis 1983; por. zwl. s. 172.
} 
na wybór teorii: należy odrzucić Freudowską oraz behawiorystyczną teorię psychologiczną. ${ }^{11}$ Być może Wolterstorff ma rację, ale jego argumenty są zupełnie nieprzekonujące. Nawet gdyby te dwie szkoły myślenia zaprzeczały „ludzkiej wolności i odpowiedzialności”, to i tak mogłoby być to zgodne $\mathrm{z}$ niektórymi chrześcijańskimi przekonaniami kontrolnymi. Co ważniejsze, ani psychologia Freudowska, ani behawiorystyczna nie wymagają negacji ludzkiej wolności i odpowiedzialności. Zachowanie człowieka nie jest, rzecz jasna, niezależne od czynników przyczynowych, a mimo to psychoanaliza Freudowska stara się określić obszary, w których pacjenci mogą uzyskać kontrolę. Psychoanaliza usiłuje rozszerzyć dziedzinę racjonalnej wolności i odpowiedzialności poprzez odkrywanie prawdziwych „przyczyn”, które pacjent może kontrolować. ${ }^{12}$ Nawet behawioryzm w psychologii można poprawnie rozumieć jako sposób badania „osoby jako układu fizycznego", ${ }^{13}$ nie uznając jednocześnie, że badana osoba jest wytacznie układem fizycznym. Psychologiczny behawioryzm jest próbą stworzenia takiej psychologii, która byłaby nauką przyrodniczą, podlegającą wymogom naturalizmu metodologicznego. Próba ta $z$ pewnością doprowadziła do różnych wartościowych odkryć. Jednakże obaj z Wolterstorffem sprzeciwiamy się nieostrożnym filozoficznym i „religijnym" wypowiedziom takich ludzi jak B.F. Skinner, według których wąski przedmiot zainteresowania tego typu psychologii stanowi całość ludzkiej jaźni. Chrześcijanin może cenić behawioryzm, potępiając zarazem chybione próby przekształcenia tej teorii psychologicznej $\mathrm{w}$ filozoficzną antropologię.

Z drugiej strony Wolterstorff szczegółowo omawia przykłady ukazujące, jak zmiany $\mathrm{w}$ rozmaitych teoriach prawidłowo, jak sądzi, do-

\footnotetext{
${ }^{11}$ Por. Wolterstorff, Reason..., s. 64 i n., 73.

${ }^{12}$ Por. C. Stephen Evans, „Must Psychoanalysis Embrace Determinism? Or Can a Psychoanalyst Be a Libertarian?", Psychoanalysis and Contemporary Thought 1984, vol. 7, no. 3, s. 339-365.

${ }^{13}$ Burrhus F. Skinner (cyt. za: Wolterstorff, Reason..., s. 64 i n.).
} 
prowadziły do zmian $\mathrm{w}$ chrześcijańskich przekonaniach kontrolnych. ${ }^{14}$ Oczywiście w takich przypadkach tak zwane przekonania kontrolne znajdują się już poza wszelką kontrolą! Nie zamierzam krytykować któregokolwiek przykładu Wolterstorffa. Bez wątpienia nasze ogólne pojmowanie wiary chrześcijańskiej zawsze może ulec udoskonaleniu za sprawą dowolnego źródła prawdy Bożej, nie wyłączając pewnych teorii naukowych. Tym, co mnie niepokoi, jest ciągłe posługiwanie się mylącym terminem ,przekonania kontrolne”. Lepszym określeniem są ,przekonania bazowe” lub — jeszcze lepiej — „przedrozumienia” (preunderstandings). Termin „przekonania kontrolne” powinien być zastrzeżony dla przekonań zakorzenionych tak głęboko, że niesłychanie rzadko ulegają zmianie. Te niepodważalne przekonania stanowią na ogół fundament naszych światopoglądów. Jeśli jednak większość przytoczonych przykładów, jak w pracy Wolterstorffa, wskazuje raczej na zmianę przekonań kontrolnych, nie zaś na posiłkowanie się nimi przy wyborze teorii naukowych, to etykietka ,przekonania kontrolne" jest niewłaściwa.

Po trzecie, skupiając się jedynie na wyborze i opracowywaniu teorii, Wolterstorff nie dostrzega najważniejszej roli autentycznie chrześcijańskich przekonań kontrolnych w wyborze i opracowywaniu podstaw różnych dyscyplin, zwłaszcza nauk przyrodniczych. Historycznie rzecz biorąc, rozmaite „światopoglądowe” przekonania kontrolne wywarły zasadniczy wpływ na wybór założeń i metodologii właściwych różnym dyscyplinom nauk przyrodniczych. ${ }^{15}$ Również tutaj, podobnie jak w przypadku teorii, powierzchowna niezgodność $\mathrm{z}$ innymi głęboko zakorzenionymi przekonaniami nie musi prowadzić do zmiany ani założeń danej dyscypliny, ani innych przekonań. Należy pamiętać o różnicach między grami językowymi. Niemniej podstawowe założenia oraz metodologie tych dyscyplin podlegają ,światopoglądowym” ocenom w większym stopniu niż konkretne teorie formułowane w ich ra-

\footnotetext{
${ }^{14}$ Por. wielokrotnie przytaczane przykłady w: WolterstorfF, Reason..., s. 80-96.

${ }^{15}$ Por. kontrowersyjne omówienia tych zagadnień w: Stanley L. JAKI, The Road to Science and the Ways to God, University of Chicago Press, Chicago 1978; Reijer HooykaAs, Religion and the Rise of Modern Science, Eerdmans, Grand Rapids 1972.
} 
mach. Podstawowe założenia i metodologia jednej dyscypliny leżą na granicy z innymi dyscyplinami. To na ich podstawie dokonuje się podziału i analizy porównawczej dyscyplin. I właśnie tych założeń i metodologii dotyczą najważniejsze zagadnienia w filozofii nauki, wliczając w to chrześcijańską filozofię nauki.

Gdyby jakaś teoria rzeczywiście okazała się sprzeczna z naszymi autentycznymi przekonaniami kontrolnymi, które bardzo silnie przyswoiliśmy, to mamy cztery możliwości. Po pierwsze, możemy zakwestionować założenia lub metodologię tej domniemanej „nauki” — jak w przypadku astrologii - i argumentować, że w istocie jest to pseudonauka. Po drugie, możemy spróbować zmienić część podstawowych założeń i metod dyscypliny, w której budząca sprzeciw teoria powstała lub została przyjęta. Jest to proces, który często — od Kopernika do czasów obecnych - prowadził do nowych odkryć naukowych oraz zmian w teoriach. Znaczące zmiany teorii rzeczywiście następowały wyłącznie wtedy, gdy uczeni $\mathrm{z}$ powodzeniem podważali niejawne bądź jawne założenia i metody danej dyscypliny. Po trzecie, możemy przyjąć, że teoria ma ograniczony zakres badań - jak w przypadku psychologii behawiorystycznej — oraz sprzeciwiać się wykorzystywaniu jej w celach ,światopoglądowych”. Po czwarte, być może nasze przekonania kontrolne wymagają ponownej oceny, aczkolwiek najrozsądniej byłoby rozważyć tę możliwość jedynie bardzo ostrożnie i dopiero po upływie jakiegoś czasu. To, co początkowo wyglądało na sprzeczność, często okazuje się niesprzeczne lub możliwe do rozwiązania w inny sposób. Krótko mówiąc, albo należy wykazać, że rozpatrywana dyscyplina jest pseudonauką, albo spróbować zmienić jej założenia lub metody, albo postarać się ograniczyć teorię do jej należytego kontekstu badawczego, albo wreszcie zmienić własne przekonania. Założenia i metody różnych dyscyplin odgrywają ważną rolę w każdej $\mathrm{z}$ tych reakcji. Mając to na uwadze i przyjmując za podstawę chrześcijańskie zobowiązania teologiczne i filozoficzne, chciałbym teraz przejść do obrony naturalizmu metodologicznego w naukach przyrodniczych. 


\section{Chrześcijańskie poparcie dla naturalizmu metodologicznego}

Jak chrześcijanie powinni podchodzić do naturalizmu metodologicznego? Istnieje sześć powodów, dla których powinniśmy przyjmować naturalistyczną metodologię nauk przyrodniczych z entuzjazmem.

Po pierwsze, chrześcijaństwo naucza, że w zjawiskach przyrody można odkryć prawidłowości i spójność. Metodologię naturalistyczną w naukach przyrodniczych można zatem zaakceptować przy założeniu, że Bóg urządził świat w sposób spójny. Kwestia istnienia Boga nie musi być podnoszona w naukach przyrodniczych, ponieważ wiara w Jego istnienie stała się już częścią historycznego podłoża współczesnej nauki. Dzięki mocy i niezawodności Boga Stwórcy możemy oczekiwać, że w stworzonym porządku naturalnym odkryjemy regularne wzorce przyczynowości i wzajemnych oddziaływań. Wzorce te często robią większe wrażenie, gdy badane są w izolacji (z pomocą naturalizmu metodologicznego) przez naukowców, którzy bezustannie badają wszelkie wzajemne relacje między faktami. W pracy naukowej teologiczne lub filozoficzne spekulacje bądź analizy nie muszą rozpraszać naszej uwagi. Niemniej, prowadząc badania naukowe w granicach naturalizmu metodologicznego, ze stanowiska pogłębionego poznania możemy darzyć Stwórcę jeszcze większym podziwem.

Po drugie, właściwie rozumiany naturalizm metodologiczny stanowi użyteczne podejście do pracy naukowej, nie przesądza to jednak o jego użyteczności w innych dziedzinach życia. Wyważone zrozumienie możliwości i ograniczeń nauk przyrodniczych pozwala dostrzec prawdziwą zasadność nienaturalistycznych wyjaśnień tych zdarzeń, które nie wchodzą w zakres badań nauk przyrodniczych.

Przykładowo farmer może uznać, że jakaś konkretna ulewa jest odpowiedzią na jego modlitwy, nie kwestionując przy tym wyjaśnień meteorologicznych — może widzieć działanie Boga w złożonych zależnościach przyczynowych, które wywierają wpływ na pogodę. Może być wdzięczny Bogu nie tylko za to, że odpowiedział na jego modlitwy, ale także za zdumiewające prawidłowości, które występują 
w przyrodzie. Podobnie lekarz może, z naukową trafnością, przepisać pacjentowi właściwe lekarstwo, dziękując zarazem Bogu za jego uzdrowienie. Dzieło Boże można dostrzec w naszych procesach fizjologicznych - nie trzeba w tym celu dokładać hipotezy Boga do naszej wiedzy o fizjologii.

W zasadzie właśnie $\mathrm{z}$ tego powodu, że metodologia nauk przyrodniczych ogranicza je do wyjaśnień naturalistycznych, każdy powinien życzliwie rozważyć także inne wyjaśnienia, które przekraczają zakres zainteresowań nauki - modlitwy, cele, stworzenie ex nihilo, indywidualną wolę. $\mathrm{W}$ istocie podstawę do oddania Bogu wielkiej chwały daje właśnie pojmowalna natura świata, możliwa do odkrycia w zgodzie z wymogami naturalizmu metodologicznego. Jednak metoda, która prowadzi do tak wielkich sukcesów w naukach przyrodniczych, w innych dyscyplinach miałaby katastrofalne skutki. Czy moglibyśmy mówić o moralności, nie odwołując się do celów, albo o teologii, nie wspominając ani słowem o Bogu?

Po trzecie, skoro dyscypliny nauk przyrodniczych kierują się naturalizmem metodologicznym, to nie mogą rościć sobie prawa, by odpowiadać na pytania ostateczne. W pewnym punkcie żadne naukowe wyjaśnienie zjawisk przyrody nie może już odpowiadać na pytanie „Dlaczego?”- wyjąwszy stwierdzenie, że dotarliśmy tak daleko, na ile w danym czasie pozwoliły nam metody nauk przyrodniczych. Czy wyjaśnienie to jest całkowicie wiążące, czy też właściwsze byłoby zastosowanie bardziej ostatecznych wyjaśnień (na przykład: „Bóg tak to urządził” albo „Bóg działa w taki sposób”), pozostaje kwestią, którą należy rozstrzygnąć poza obrębem nauk przyrodniczych. Gdyby nie rygory naturalizmu metodologicznego, niektórzy mogliby zbyt szybko zaprzestać badań naukowych i spocząć na laurach, zadowalając się wyjaśnieniami ostatecznymi. Niemniej jednak naturalizm metodologiczny w naukach przyrodniczych i chrześcijańskie wyjaśnienia ostateczne są ze sobą w pełni zgodne. Niestety, rozmaite wyjaśnienia ostateczne propagowane są jako wyniki badań naukowych. Skoro nie mamy istotnych powodów, by wierzyć, że cała prawda ma charakter naukowy, i skoro nauki przyrodnicze ograniczone są naturalizmem 
metodologicznym, to rozstrzygając sprawy ostateczne, dotyczące na przykład światopoglądu lub sensu i podstawowych wartości w życiu, musimy polegać również na źródłach pozanaukowych.

Na przykład zrozumienie roli mutacji genetycznych i doboru naturalnego w całej historii rasy ludzkiej należy do dziedziny badań naukowych, ale pytanie o rzeczywiste pochodzenie ludzi ma charakter ostateczny. Przekracza ono zakres kompetencji nauk przyrodniczych, przyjmujących naturalistyczną metodologię, ponieważ dotyczy podstawowego sensu i celu naszego istnienia. Jest to zagadnienie „światopoglądowe", nie zaś problem możliwy do rozwiązania w ramach nauk przyrodniczych. Gdybyśmy rozpatrywali takie ostateczne pytania tylko w zgodzie z wytycznymi naturalizmu metodologicznego, to nasze wnioski wspierałyby naturalizm metafizyczny. Musimy dokładniej przyjrzeć się charakterystycznym cechom pytań ostatecznych i udzielając na nie odpowiedzi — konsekwentnie unikać stosowania wyłącznie tendencyjnych metod (takich jak naturalizm metodologiczny).

Po czwarte, chrześcijanie nie powinni czuć się skrępowani naturalizmem metodologicznym w naukach przyrodniczych, ponieważ Bóg rozciąga władzę nad całym życiem. Boska władza nad wszelkimi aspektami naszego życia nie zależy ani od tego, czy wymusimy uwzględnienie Boga w każdej dyscyplinie lub sytuacji, ani od tego, czy teologia góruje nad innymi dyscyplinami. Jak wskazywał Abraham Kuyper, jeśli Bóg włada całym życiem, to panuje również nad każdą jego częścią. Wewnętrzna struktura działalności naukowej stanowi część Królestwa Bożego. Tak więc jakiekolwiek manipulowanie naukami przyrodniczymi, by dopasować je do celów teologów, kościołów czy rządów, jest przejawem braku wiary. W sferze objętej kompetencjami nauk przyrodniczych wolno nam badać dzieła Boże bez konieczności jawnego odnoszenia się do Osoby Boga lub nawet Jego istnienia. ${ }^{16}$ Dzieła Boga objawione są każdemu i wszyscy mogą

\footnotetext{
${ }^{16}$ Por. zwł. Abraham KuYPER, Lectures on Calvinism, Eerdmans, Grand Rapids 1931, wykład IV.
} 
je badać — nawet ci, którzy Go nie znają.

Po piąte, Wcielenie powinno wyzwolić chrześcijan od wszelkich obaw o naturalizm metodologiczny w naukach przyrodniczych, kiedy bowiem Słowo ciałem się stało, Syn Boży nie zawładnął kondycją ludzką, lecz uszanował jej ograniczenia. Zstąpił do tego świata, nie zmieniając go. Przez dziewięć miesięcy był płodem w łonie matki. Dorastał w naturalnych okolicach Nazaretu. Cierpiał razem z nami i umarł. Biologicznie niczym się od nas nie różnił. Nie ulega wątpliwości, że miał wyjątkowy cel, a poprzez zmartwychwstanie pokonał śmierć. W oczach ludzi i Boga był jednak człowiekiem. Przeto ucieleśnianie idei naukowych w postaci naczyń włoskowatych, walencyjności czy gluonów, o których można mówić w ramach naturalizmu metodologicznego, nie powinno uwłaczać naszej godności.

Wreszcie, naukowiec chrześcijański powinien bez mrugnięcia okiem zaakceptować naturalizm metodologiczny w pracy naukowej, ponieważ życie to coś znacznie więcej niż dziedziny badań naukowych. Teorie naukowe są $\mathrm{z}$ konieczności niezupełne, ponieważ świat to nie tylko materia i energia. Pracując w laboratorium lub analizując dane przy biurku, możemy postrzegać świat wyłącznie w kategoriach materii i energii. W końcu jest to właściwy przedmiot zainteresowań nauk przyrodniczych. Tragikomedia rozpoczyna się wówczas, gdy naukowiec zapomina o swoim człowieczeństwie i twierdzi, że jego materialno-energetyczny obraz świata jest kompletny. Może być to najsmutniejszy z dowcipów o ,profesorze zapominalskim”. Najwyraźniej naukowcy zbyt łatwo zapominają o tym, żeby własne teorie odnieść do siebie samych. Gdzie w materialno-energetycznym obrazie świata jest miejsce dla miłości naukowca do własnej żony, nadziei na spełnienie marzeń swoich dzieci, pragnienia uznania przez innych naukowców czy oddania prawdzie naukowej? Czy drzewa muszą przesłaniać uczonemu las? Czy nie może dostrzec osoby, a tylko kości i mięśnie? $\mathrm{Na}$ pewno przecież spogląda w lustro podczas golenia! Gdzie w jego teoriach miejsce dla wściekłości na asystenta laboratoryjnego lub podziwu dla urody i wdzięku studentki, którą wypatrzył 
z okna!? Czy mógłby utracić zdolność spostrzegania? Byłoby to przygnębiające.

Pozwoliwszy, by nauka swobodnie kierowała się naturalizmem metodologicznym, łatwiej będzie można wskazywać autentyczne ograniczenia nauk przyrodniczych. Wiele prawd leży poza ich zasięgiem - na przykład te, dotyczące ludzkiej natury, potrzeb, właściwych wartości i sensu życia, albo tego, skąd pochodzimy i dokąd zmierzamy. Pomyślmy przecież: podręcznik biologii nie pomaga wiele w wyborze partnerki, podobnie jak poradnik mechanika samochodowego nie inspiruje pomysłów na wakacje. (Moglibyśmy być już po rozwodzie i w ogóle nie ruszyć się z domu!) Jeśli pozwolimy, by nauki przyrodnicze ograniczały się do swoich przedmiotów badań zgodnie $\mathrm{z}$ wymogami naturalizmu metodologicznego, to wówczas łatwiej uda się obronić inne źródła prawdy. Natomiast nacisk, by w naukach przyrodniczych mówiono o Bogu, jest równoznaczny z nierozsądnym podporządkowaniem się współczesnemu mitowi scjentyzmu, w myśl którego cała prawda zawiera się w nauce.

Naturalizm metodologiczny w naukach przyrodniczych nie musi zagrażać chrześcijanom. (1) $\mathrm{Z}$ pewnością oczekujemy przecież, że stworzony porządek ma jakąś strukturę. Niemniej (2) ten wąski, naturalistyczny obszar zainteresowań jest wartościowy tylko w obrębie nauki, zaś (3) problemy spoza tego obszaru należy rozpatrywać w świetle innych metodologii. Ponadto (4) fakt, że w naukach przyrodniczych nie wspomina się o Bogu, nie wyklucza wpływu Jego Obecności. Wręcz przeciwnie, (5) Jego Inkarnacja potwierdza, że osadzenie w porządku naturalnym w niczym $\mathrm{Mu}$ nie przeszkadza. Wreszcie, (6) nie powinniśmy na siłę wprowadzać do nauki dociekań teologicznych, ponieważ nauki przyrodnicze z konieczności są niezupełne. Nasze życie jest czymś znacznie więcej niż mogą badać nauki przyrodnicze, te zaś muszą respektować naturalistyczną metodologię. A skoro już o tym mowa, cóż może być bardziej naturalne? 